\title{
Construction of Oscillographic Square Wave Polarograph*
}

\author{
By \\ Yukio Saito and Koichi Okamoto \\ (Research Laboratoyy of Sankyo Co. Ltd., Shinagawa, Tokyo)
}

(Received June 4, 1962)

\section{Introduction}

Oscillographic polarography is classified into two types of Heyrovský-Forejt's current control system and Randles-Sevčik's potential control system.

These oscillographic polarographic methods have the merit of measuring the faradaic current under the steep concentration gradient of the depolarizer at the vicinity of the electrode surface. But the unfavorable overlapping of capacity current on faradaic current is pronounced as the potential or current scans more rapidly, and accordingly the selective and precise measurement of faradaic current become more complicated.

The authors employed Barker's square wave method ${ }^{1)}$ coupled with the modified Randles-Sevčik's single sweep method, ${ }^{45}$. In this paper the circuit, named an oscillographic square wave polarograph, is presented in detail, including improvement on the elimanation of capacity current and the method of scanning of DC applied potential.

\section{Theoretical}

\section{Improvement on the Elimination of Capacity Current.}

In Barker's square wave polarograph faradaic currents are selectively picked up by a gate circuit after capacity current component decaysed almost to zero. In a pen-recording device it is rather easy to select the period in the square wave cycle long enough for the complete decay of the capacity current. On the contrary in oscillographic method the period to be chosen should be considerably short because of the rapid scanning of the DC

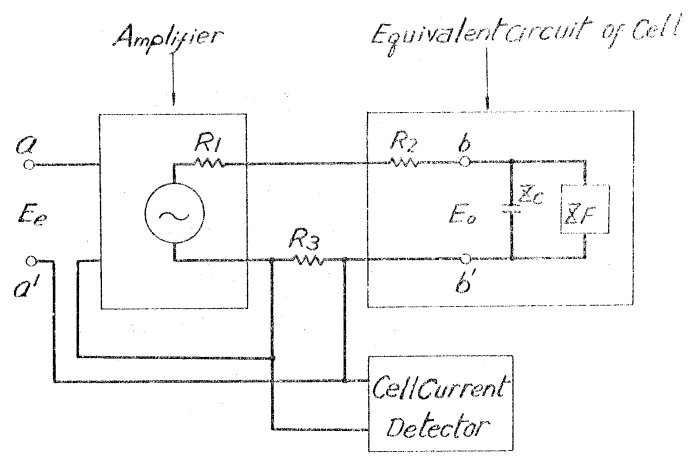

Fig. 1. Equivalent circuit of compensator and cell. applied potential. Under this condition the selective detection of faradaic current becomes difficult, because capacity current does not decay even at the operation time of the gating circuit. In order to reduce the time of decay of the capacity current some attempts were tried to diminute the internal impedance of the appliedvoltage-source and the series resistance in the cell circuit.

The more effective method for

* Oscillographic Square Wave Polarography Part I. 
this purpose is to use a positive feedback technique. When current is fed back into the input terminal of the amplifier, the internal impedance looking back from the terminal of the electric double layer capacity in the equivalent circuit of the cell (Fig. 1) to the applied voltage source can be decreased considerally. The theoretical consideration on this compensation method is given on the equivalent circuit in Fig. 1 as follows :

Square wave potential and DG potential are applied to the terminal $a-a^{\prime}$, and then connected to the cell terminal after the amplification by DC amplifier (gain $=u$ ), The ohmic drop across $R_{3}$ is fed back into the input of DG amplifier, and at the same time it is amplified and detected as electrolytic current. The relation of the potential difference between the terminal $\mathrm{a}-\mathrm{a}^{\prime}\left(E_{e}\right)$ to the potential difference between the terminal $\mathrm{b}-\mathrm{b}^{\prime}\left(E_{o}\right)$ is given by eq. (1).

$$
E_{o} / E_{e}=\mu \frac{\left(Z_{c} \cdot Z_{f}\right) /\left(Z_{c}+Z_{f}\right)}{R_{1}+R_{2}+R_{3}(1-\mu)+\left(Z_{c} \cdot Z_{f}\right) /\left(Z_{c}+Z_{f}\right)}
$$

where : $R_{1}$ : the internal impedance of DC amplifier.

$R_{2}$ : the series resistance of the cell circuit.

$Z_{c}:$ the impedance of the electric double layer capacity at the electrode interface.

$Z_{f}$ : faradaic impedance.

From eq. (1), if the following relation;

$$
O \leqq R_{1}+R_{2}+R_{3}(1-\mu)<R_{1}+R_{2}+R_{3}
$$

is satisfied, the internal impedance looking back from the terminal b- $b^{\prime}$ to the DC amplifier should be smaller. And it follows the relation;

$$
O<R_{3} \leqq\left(R_{1}+R_{2}\right) /(\mu-1), \quad \text { where } \mu>1 \text {. }
$$

When in eq. (3) $R_{3}$ is equal to the right term, $\left(R_{1}+R_{2}\right) /(\mu-1)$, the internal impedance should be $0 \mathrm{ohm}$. Thus the time constant of capacity current could be reduced to 0 sec. theoretically.

\section{Start Signal Generator Circuit.}

Several devices on the start signal generation for the sweeping of DC potential had been reported, for example Snowden et al. ${ }^{2)}$ and David et al..$^{3)}$ utilized the sharp change of the electrode current at the instant of the fall of mercury drop, while DG polarization of $-2 \mathrm{~V}$. is applied to the drop.

In our polarograph, above technique is not suitable as the logic circuit becomes very much complicated. Therefore, large capacity current at $0 \mathrm{~V}$. was utilized to operate the monostable multivibrator to generate the start signal.

\section{Addition of the Anodic Sweeping Process.}

DG applied voltage sweeps from 0 to $-2 \mathrm{~V}$. and no reverse sweep was equipped in single sweep Randles' oscillographic polarograph.

It is expected that if the simultaneous and comparative observations on cathodic and anodic waves are possible, much of the interesting or useful knowledges for the study on the mechanism of electrode reaction will be obtained. Therefore in our polarograph the triangular sweep system ${ }^{4}$ was equipped in which DG potential begin to sweep from 0 to $-2 \mathrm{~V}$. (cathodic process) and then almost continuously returned to $0 \mathrm{~V}$. again (anodic process).

\section{Experimental}

Practical circuit is explained in this section. 


\section{1) Block Diagram.}

Block diagram was shown in Fig. 2. The operation process is as follows: The square wave voltage, being generated by astable multivibrator, is reduced to $c a .3 \mathrm{kc} / \mathrm{s}$ of the fre-

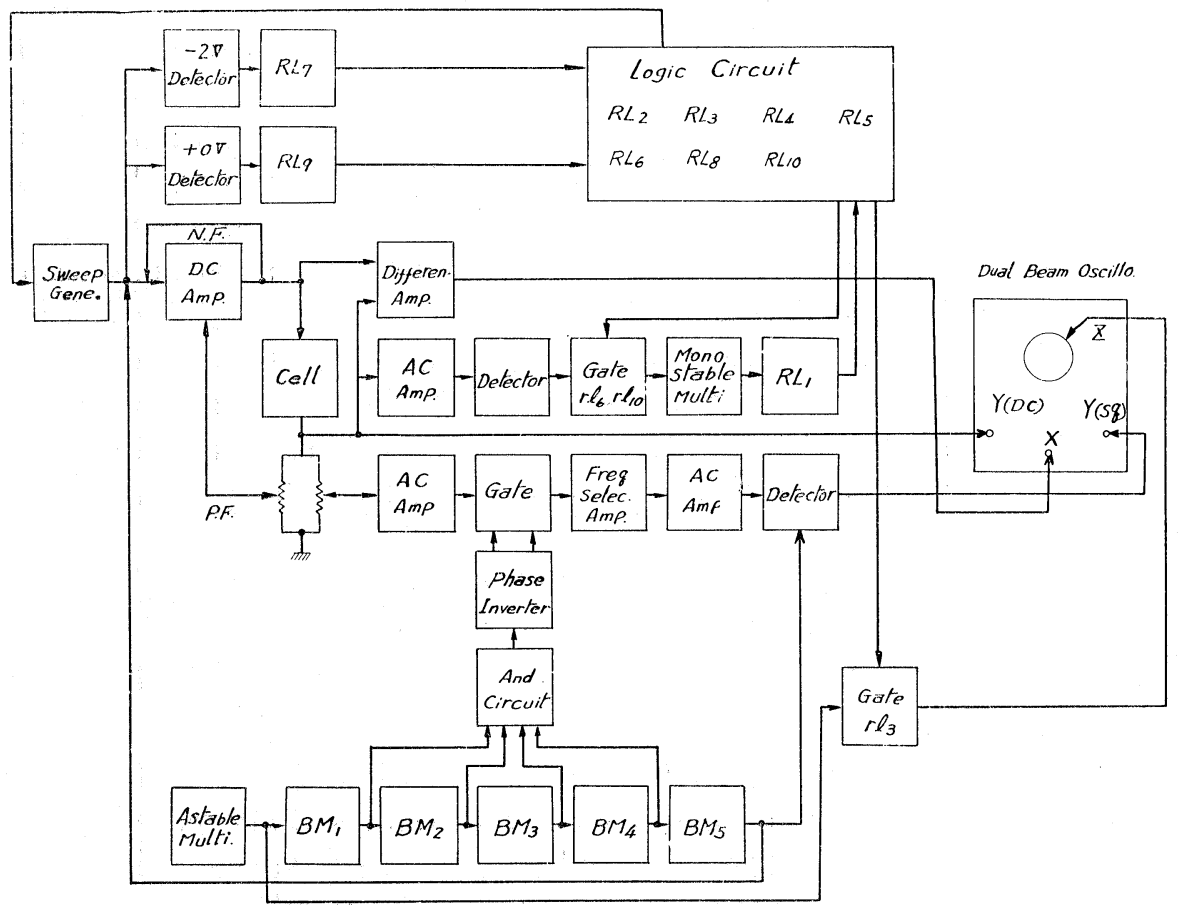

Fig. 2. Block diagram.

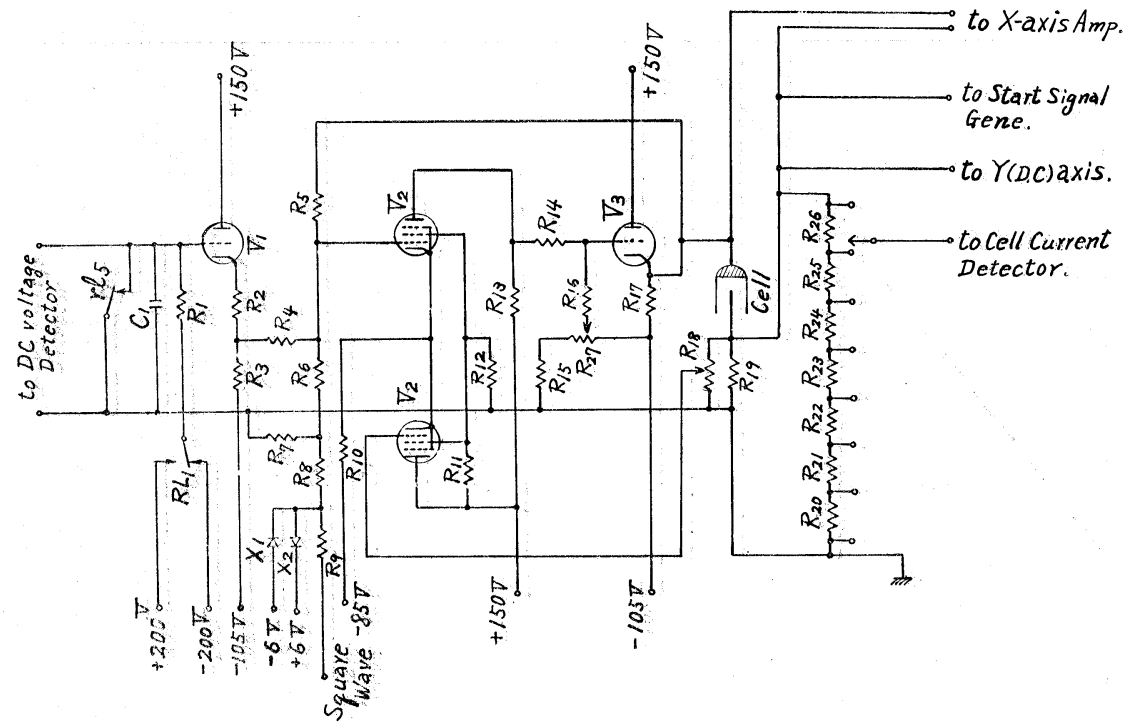

Fig. 3. Compensator circuit.

$\mathrm{R}_{1}: 1 \mathrm{M}, \mathrm{R}_{2}: 7.5 \mathrm{~K}, \mathrm{R}_{3}, \mathrm{R}_{13}: 20 \mathrm{~K}, \mathrm{R}_{4}, \mathrm{R}_{5}, \mathrm{R}_{6}, \mathrm{R}_{8}, \mathrm{R}_{12}: 50 \mathrm{~K}, \mathrm{R}_{7}, \mathrm{R}_{23}: 50 \mathrm{~K}$,

$\mathrm{R}_{9}, \mathrm{R}_{15}, \mathrm{R}_{27}: 5 \mathrm{~K}, \mathrm{R}_{10}: 15 \mathrm{~K}, \mathrm{R}_{11}, \mathrm{R}_{17}: 10 \mathrm{~K}, \mathrm{R}_{14}, \mathrm{R}_{16}: 100 \mathrm{~K}, \mathrm{R}_{18}: 1 \mathrm{~K}, \mathrm{R}_{19}$ : $200 \mathrm{~K}, \mathrm{R}_{20}, \mathrm{R}_{21}: 10, \mathrm{R}_{22}: 30, \mathrm{R}_{24}: 100, \mathrm{R}_{25}: 300, \mathrm{R}_{26}: 500 . \mathrm{C}_{1}: 50 \mu . \mathrm{X}_{1}$, $\mathrm{X}_{2}: \mathrm{SD} 60 . \mathrm{V}_{1}, \mathrm{~V}_{3}: 1 / 2-12 \mathrm{AU} 7, \mathrm{~V}_{2}: 6 \mathrm{AU} 6$. 
quency and to $10 \mathrm{mV}_{p-p}$ of the amplitude by five-stage bistable multivibrator, then it is superimposed to the DC voltage being generated by a sweep generator. They are applied to the cell through the compensator circuit (DG Amp. in Fig. 2 and also refer to Fig. 3).

The AC component of cell currents is detected by the series resistance, then faradaic current component in the amplified cell currents is selectively picked up by the gate circuit (refer to Fig. 7). The square wave signal, being picked up by the gate circuit, is protected from the noise of gating signal etc. by the frequency selective amplifier, and then applied to the $\mathrm{Y}_{s q}$-axis of a dual-beam oscilloscope (Nihon Koden Kogyo's Model VC-6) after the amplification and the passage through the phase sensitive detector.

The potential at the cell terminals is detected by the differential amplifier and the output of it is applied to the X-axis of the oscilloscope. The triangular DG potential sweep is applied to the cell once a single drop life by synchronizing the sweep generator with the dropping of the mercury electrode (see later). The $-2 \mathrm{~V}$-detector by which is turned back the directon of DG potential sweep at $-2 \mathrm{~V}$. and the $+0 \mathrm{~V}$.-detector by which is released the logic circuit to the initial state at $+0 \mathrm{~V}$, are both equipped in the sweep generator.

Besides these, the blanking relay was set to control the brightness of the cathode-ray tube in order to observe the polarogram more clearly.

The individual parts in the block diagram are explained in the following sections.

\section{2) Compensalor Circuit.}

The practical compensator circuit (refer to section 1) is a negative feedback amplifier (gain, $\mu=2$ ) which is composed of the differential amplifier and the cathode-follower. (Fig. 3). Positive feedback is carried out by applying the electrode current signal which was detected by a potentiometer, to the input of the differential amplifier. When the compensator is operating normally, capacity current component decays to zero after about 32

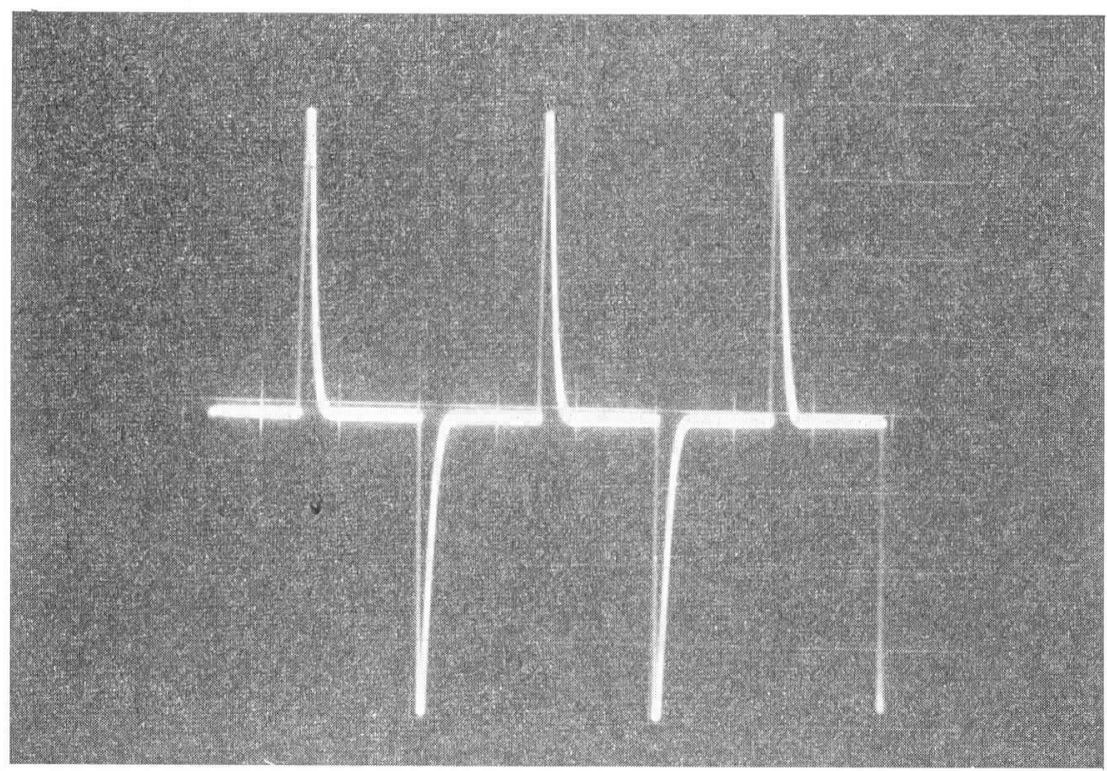

Fig. 4. Capacity current by a dummy cell ( $0.5 \mu \mathrm{F}$ condenser and $100 \Omega$ resistance) when the time constant was compensated by positive feedback technique. $320 \mu \mathrm{sec} / 3 \operatorname{div}$. (abscissa) 


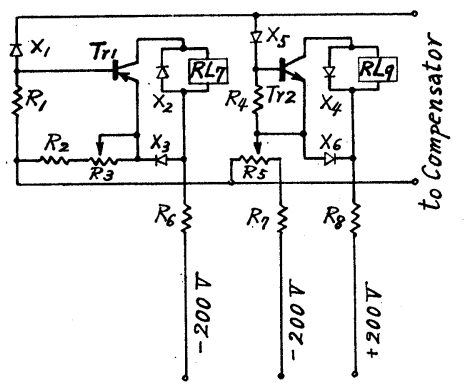

Fig. 5. DG Voltage Dector.

$\mathrm{R}_{1}, \mathrm{R}_{\mathbf{4}}: 10 \mathrm{~K}, \mathrm{R}_{2}: 150, \mathrm{R}_{3}, \mathrm{R}_{5}$ : $100, \mathbf{R}_{6}, R_{8}: 20 \mathrm{~K}, \mathrm{R}_{7}: 13 \mathrm{~K} . \mathrm{X}_{1}$, $\mathrm{X}_{5}: \mathrm{SD104}, \mathrm{X}_{2}, \mathrm{X}_{4}: \mathrm{SD} 54, \mathrm{X}_{3}, \mathrm{X}_{6}$ : RD16A. $\operatorname{Tr}_{1}:$ 2SB101, $\operatorname{Tr}_{2}: 2 \mathrm{SD} 11$. $\mu$ sec. (Fig. 4). It may disappears after about 580 $\mu \mathrm{sec}$, if no positive feedback is operating.

3) $D C$ potential detector.

The relay for the detection of $-2 \mathrm{~V}$. and + $0 \mathrm{~V}$. were operated by the current which flowed through the silicon diode, SD 104, having clipping properties as shown in Fig. 5. The zener diode, RD 16A, was also employed to exclude the undesired influences from the relay current; the reference potential which determined the clipping level of the silicon diode, was obtained by the ohmic drop of the relay current across a series resistance.

\section{4) The Amplifer for the Detection of Square Wave Current.}

As shown in Figs. 6 and 8, ordinary circuits were employed for this purpose. The clipping diode, $\mathrm{SD} 60$, was used to release the amplifier from the saturated state.

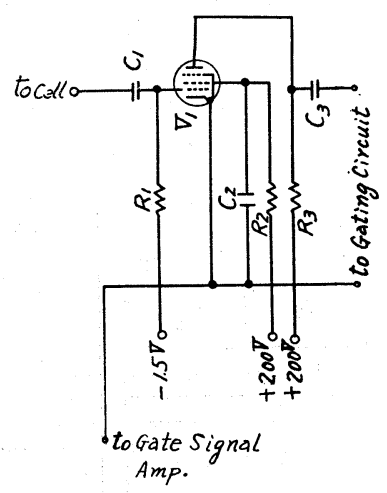

Fig. 6. Preamplifier.

$\mathrm{R}_{1}: 1 \mathrm{M}, \mathrm{R}_{2}: 50 \mathrm{~K}, \mathrm{R}_{3}: 20 \mathrm{~K}$. $\mathrm{C}_{1}: 0.005 \mu, \mathrm{C}_{2}: 4 \mu, \mathrm{G}_{3}: 0.25$

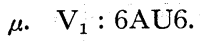

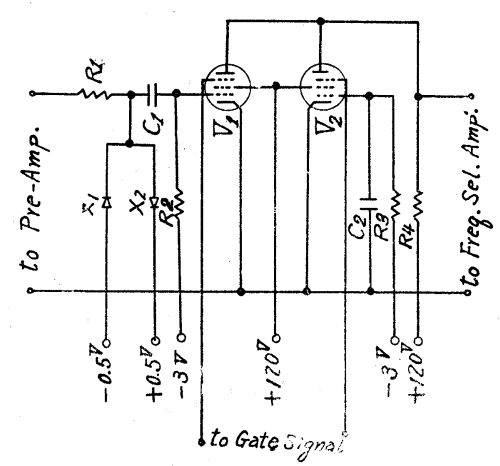

Fig. 7. Gate circuit.

$\mathrm{R}_{1}: 50 \mathrm{~K}, \mathrm{R}_{2}, \mathrm{R}_{3}: 1 \mathrm{M}, \mathrm{R}_{4}: 15 \mathrm{~K}$. $\mathrm{C}_{1}, \mathrm{C}_{2}: 0.01 \mu . \quad \mathrm{X}_{1}, \mathrm{X}_{2}: \mathrm{SD} 60 . \quad \mathrm{V}_{1}$, $\mathrm{V}_{2}: 6 \mathrm{AS} 6$.

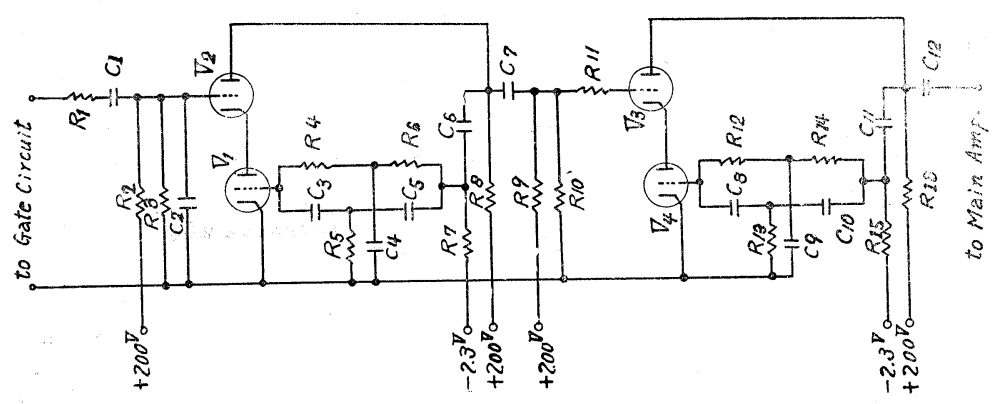

Fig. 8. Frequency Selective Amplifier.

$\mathrm{R}_{1}, \mathrm{R}_{4}, \mathrm{R}_{6}, \mathrm{R}_{12}, \mathrm{R}_{14}: 100 \mathrm{~K}, \mathrm{R}_{2}: 300 \mathrm{~K}, \mathrm{R}_{3}: 150 \mathrm{~K}, \mathrm{R}_{5}, \mathrm{R}_{13}: 50 \mathrm{~K}$, $\mathrm{R}_{7}, \mathrm{R}_{11}, \mathrm{R}_{15}: 1 \mathrm{M}, \mathrm{R}_{8}, \mathrm{R}_{16}: 40 \mathrm{~K}, \mathrm{R}_{9}: 500 \mathrm{~K}, \mathrm{R}_{10}: 250 \mathrm{~K} . \mathrm{C}_{1}, \mathrm{C}_{2}$, $\mathrm{C}_{3}, \mathrm{C}_{5}, \mathrm{C}_{8}, \mathrm{C}_{1^{n}}: 500 \mathrm{P}, \mathrm{C}_{4}, \mathrm{C}_{9}: 0.001 \mu, \mathrm{C}_{6}, \mathrm{C}_{11}: 0.25 \mu, \mathrm{C}_{7}, \mathrm{C}_{12}$ : $0.005 \mu . \quad \mathrm{V}_{1}, \mathrm{~V}_{2}, \mathrm{~V}_{3}, \mathrm{~V}_{4}: 1 / 2-12 \mathrm{AU} 7$. 
5) The Gate Circuit.

The gate circuit was shown in Fig. 7. Gating interval was set to 10 usec; corresponding to $1 / 16$-values to the half-period (160 $\mu \mathrm{sec})$ of square wave potential. The centre of the gate was after $145 \mu \mathrm{sec}$ from the each start point of square wave.

Stable gate signal is obtained by the And-circuit (Fig.9) to which the outputs from bistable multivibrators (Fig. 10) were applied in the manner as follows :

Gate signal $=\mathrm{BM}_{1}+\mathrm{BM}_{2}+\mathrm{BM}_{3}+\mathrm{BM}_{4}$ 6) Blanking Relay Circuit.

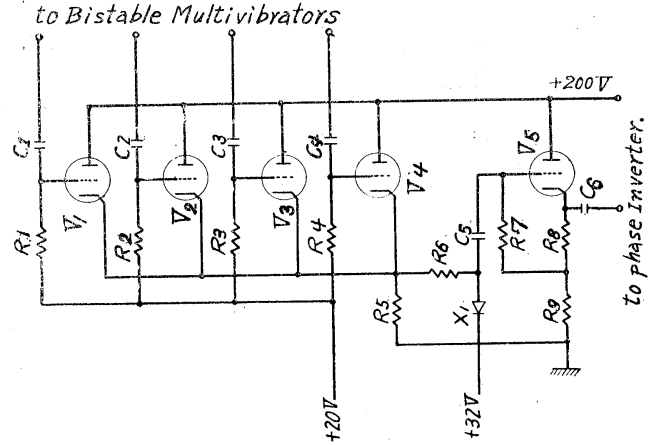

Fig. 9. And circuit.

$\mathrm{R}_{1}, \mathrm{R}_{2}, \mathrm{R}_{3}, \mathrm{R}_{4}, \mathrm{R}_{7}: 1 \mathrm{M}, \mathrm{R}_{5}, \mathrm{R}_{6}: 5 \mathrm{~K}, \mathrm{R}_{8}: 2 \mathrm{~K}$, $\mathrm{R}_{9}: 15 \mathrm{~K} . \quad \mathrm{C}_{1}, \mathrm{C}_{2}, \mathrm{C}_{3}, \mathrm{C}_{4}, \mathrm{C}_{5}: 0.002 \mu, \mathrm{C}_{6}: 0.25 \mu$ $\mathrm{V}_{1}, \mathrm{~V}_{2}, \mathrm{~V}_{3}, \mathrm{~V}_{4}, \mathrm{~V}_{5}: 1 / 2-12 \mathrm{AU} 7$.

The brightness of the cathode-ray tube is controlled by applying the square wave current of $96 \mathrm{kc} / \mathrm{s}$ being derived from the oscillator, to the Z-axis of the oscilloscope through the blanking relay $\left(\mathrm{rl}_{3}\right)$ as shown in Fig. 10.

7) The Amplifier for the Potential Axis.

The potential between the cell terminals is lead to the X-axis of the oscilloscope through the differential amplifier (refer to Fig. 2) in order to detect the potential independently of the resistance for current detection.

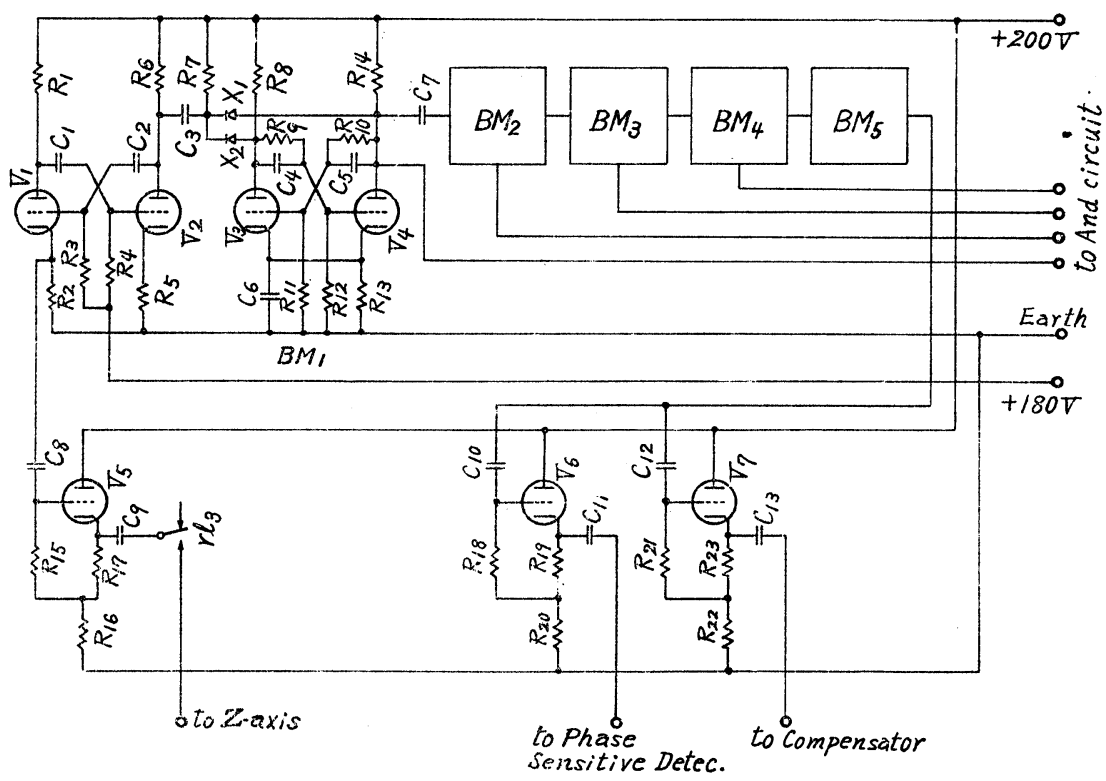

Eig. 10. Bistable Multivibrator.

$\mathrm{R}_{1}, \mathrm{R}_{6}, \mathrm{R}_{8}, \mathrm{R}_{14}: 5 \mathrm{~K}, \mathrm{R}_{2}, \mathrm{R}_{5}: 1 \mathrm{~K}, \mathrm{R}_{3}, \mathrm{R}_{4}: 250 \mathrm{~K}, \mathrm{R}_{7}, \mathrm{R}_{13}: 10 \mathrm{~K}, \mathrm{R}_{9}, \mathrm{R}_{10}$, $\mathrm{R}_{11}, \mathrm{R}_{12}: 50 \mathrm{~K}, \mathrm{R}_{15}, \mathrm{R}_{18}, \mathrm{R}_{21}: 1 \mathrm{M}, \mathrm{R}_{16}, \mathrm{R}_{20}, \mathrm{R}_{22}: 15 \mathrm{~K}, \mathrm{R}_{17}, \mathrm{R}_{19}, \mathrm{R}_{23}: 2 \mathrm{~K}$. $\mathrm{C}_{1}, \mathrm{C}_{2}: 100 \mathrm{P}, \mathrm{C}_{3}: 10 \mathrm{P}, \mathrm{C}_{4}, \mathrm{C}_{5}: 20 \mathrm{P}, \mathrm{C}_{6}: 0.01 \mu, \mathrm{C}_{7}: 50 \mathrm{P}, \mathrm{C}_{8}, \mathrm{C}_{10}, \mathrm{C}_{12}: 0.002$ $\mu, \mathrm{C}_{9}: 0.005 \mu, \mathrm{C}_{1}, \mathrm{C}_{13}: 0.25 \mu . \mathrm{X}_{i}, \mathrm{X}_{2}:$ SD104. $\mathrm{V}_{1}, \mathrm{~V}_{2}, \mathrm{~V}_{3}, \mathrm{~V}_{4}, \mathrm{~V}_{5}, \mathrm{~V}_{6}, \mathrm{~V}_{7}$ : 1/2-12AU7. 


\section{8) Start Signal Generator Gircuit.}

The start signal is obtained by the circuit as shown in Fig. 11 in the following manner: The AC cell current is amplified and then rectified by diodes, SD 104. The envelope of it is obtained by $\mathrm{CR}$-filter, $\mathrm{C}_{6}$ and $\mathrm{R}_{9}$, and is gated by $\mathrm{rl}_{6}$ and $\mathrm{rl}_{10}$, then differentiated by $C_{8}$ and $R_{11}$. Finally the pulse obtained is added to the monostable multivibrator.

\section{9) Logic Circuit.}

The logic circuit as in Fig. 12 was employed in order to operate the circuits, Figs. 2, 3,10 , and 11 , systimatically.

The running process of the logic circuit is explained according to Fig. 13.

At first the square wave current which increases gradually with the growth of a mercury drop and suddenly decreases to zero at the fall of it (Fig. 13-1), is changed to a drop pulse (Fig. 13-2) by the circuit as in Fig. 11. The monostable multivibrator with $\mathrm{RL}_{1}$ is operated by this pulse (Fig. 13-3). Then $\mathrm{RL}_{1}$ releases $\mathrm{RL}_{2}$ from self-holding state (Fig. 134). After the releases of the monostable multivibrator and $\mathrm{RL}_{1}$ (Fig. 13-3), the blanking relay $\mathrm{RL}_{3}$ (Fig. 14) works. Then $\mathrm{RL}_{10}$ cut off the signal (Fig. 13-5) for the monostable multivibrator (Fig. 11). And at the same time, $\mathrm{RL}_{4}$ works, by which is given a short time interval; the response time of $\mathrm{RL}_{4}$. Then $\mathrm{RL}_{5}$ works after the short time interval and follows the DG voltage sweep from $0 \mathrm{~V}$. to $-2 \mathrm{~V}$. (Fig. 13-6 and -11). RL $\mathrm{R}_{6}$ operates late to $\mathrm{RL}_{5}$ (Fig. 13-7), by which the signal for the monostable multivibrator is cut off in the same manner as $\mathrm{RL}_{10}$. When the $\mathrm{DC}$ voltage reaches to $-2 \mathrm{~V}$, $-2 \mathrm{~V}$.-detector operates

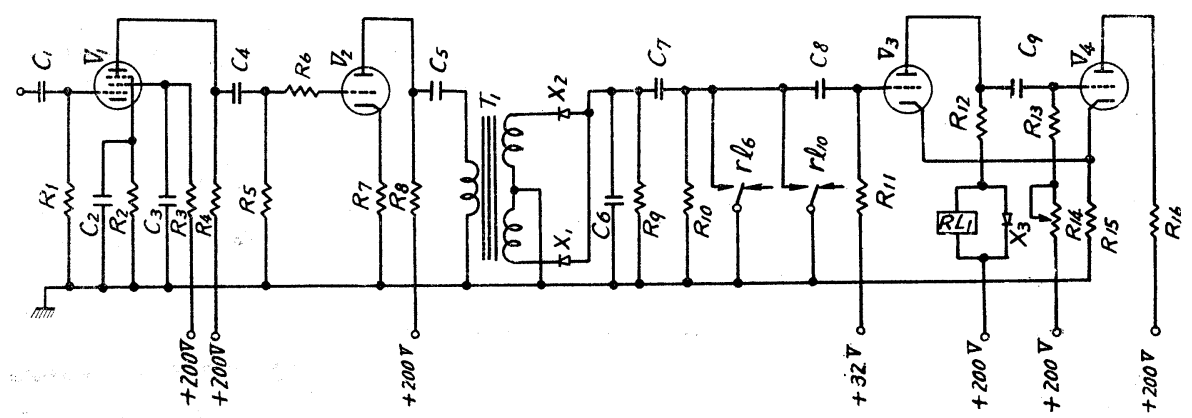

Fig. 11. Start ${ }_{i a}^{-}$signal Generator.

$\mathrm{R}_{1}, \mathrm{R}_{3}, \mathrm{R}_{5}, \mathrm{R}_{6}: 500 \mathrm{~K} \mathrm{R}_{2}: 2 \mathrm{~K}, \mathrm{R}_{4}, \mathrm{R}_{9}, \mathrm{R}_{10}: 250 \mathrm{~K}, \mathrm{R}_{7}: 1 \mathrm{~K}, \mathrm{R}_{8}: 50 \mathrm{~K}, \mathrm{R}_{11}$ : $200 \mathrm{~K}, \mathrm{R}_{12}: 8 \mathrm{~K}, \mathrm{R}_{13}: 100 \mathrm{~K}, \mathrm{R}_{14}: 1 \mathrm{M}, \mathrm{R}_{15}: 5 \mathrm{~K}, \mathrm{R}_{16}: 10 \mathrm{~K} . \mathrm{G}_{1}, \mathrm{C}_{4}: 0.005$ $\mu, \mathrm{C}_{2}: 25 \mu, \mathrm{C}_{3}, \mathrm{C}_{5}: 4 \mu, \mathrm{C}_{6}, \mathrm{C}_{8}: 0.1 \mu, \mathrm{C}_{7}: 0.25 \mu, \mathrm{C}_{9}: 15 \mu . \mathrm{X}, \mathrm{X}_{2}: \mathrm{SD} 104$, $\mathrm{X}_{3}: \mathrm{SD} 60 . \mathrm{V}_{1}: 6 \mathrm{AU} 6, \mathrm{~V}_{2}, \mathrm{~V}_{3}, \mathrm{~V}_{4}: 1 / 2-12 \mathrm{AU} 7$.

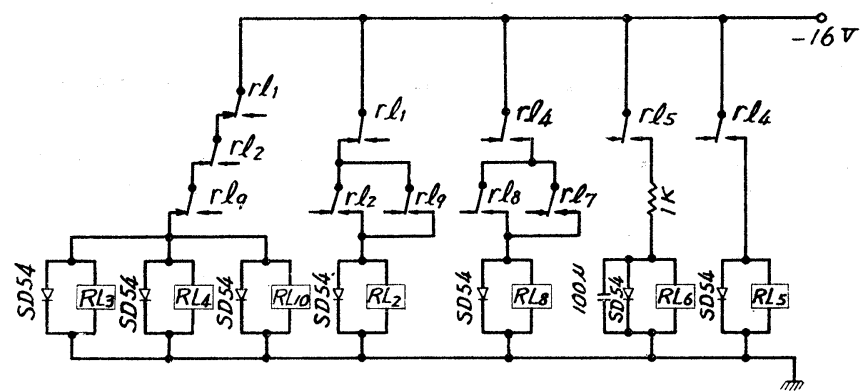

Fig. 12. Logic circuit. 


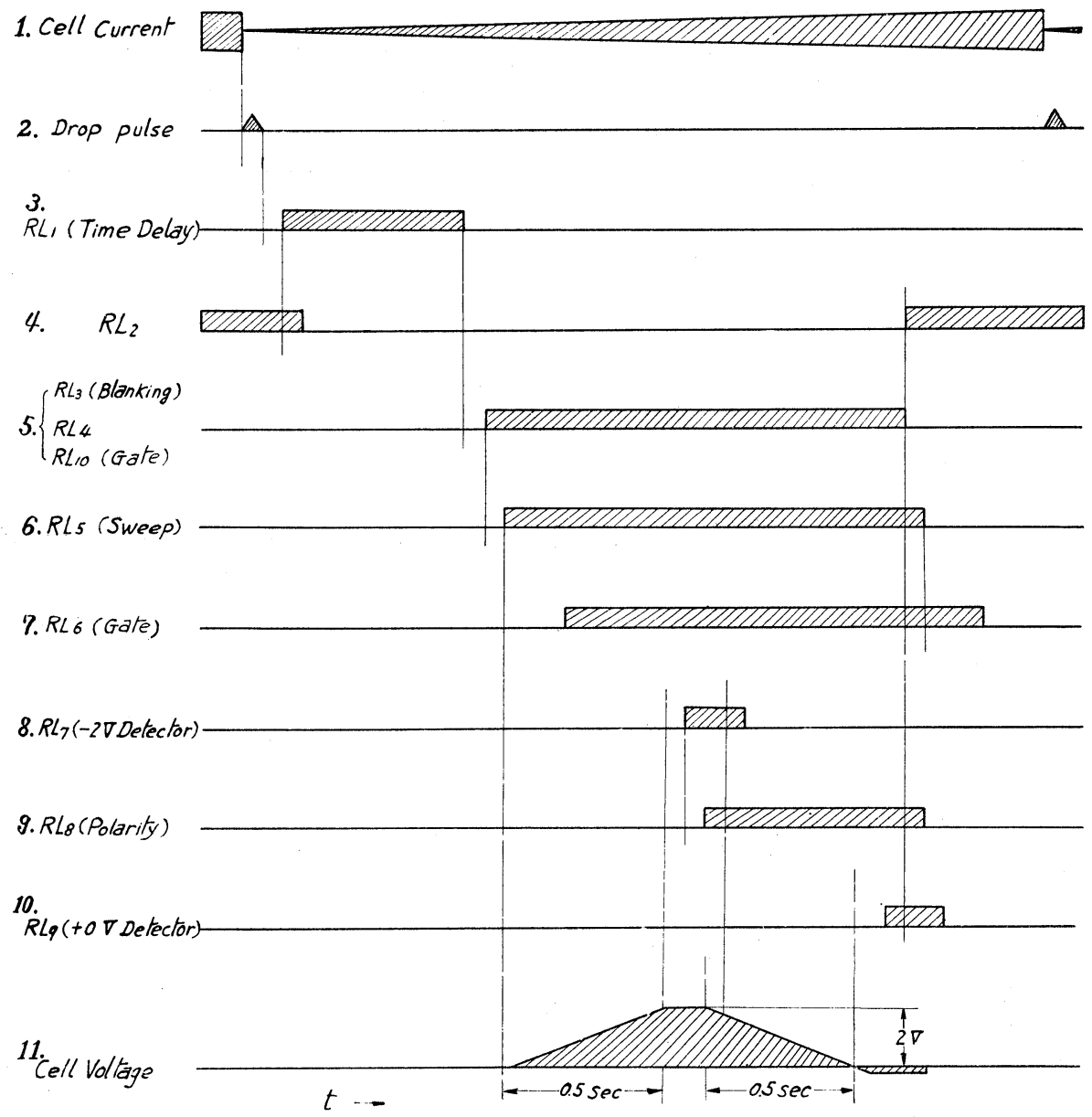

Fig. 13. Running process of logic circuit.

and it follows the operation of $\mathrm{RL}_{7}$ (Fig. 13-8) by which $\mathrm{RL}_{8}$ is self-holded (Fig. 13-9), so the DC voltage begin to sweep reversely to $0 \mathrm{~V}$. (Fig. 13-11). When DC voltage reaches slightly positive values beyond $0 \mathrm{~V} ., \mathrm{RL}_{9}$ is operated by the $+0 \mathrm{~V}$.-detector (Fig. 13-10). Accordingly $\mathrm{RL}_{2}$ come to be self-hold, then $\mathrm{RL}_{3}, \mathrm{RL}_{4}$ and $\mathrm{RL}_{10}$ are released one by one. They decrease the brightness of the cathode-ray tube, release $\mathrm{RL}_{8}$, change the polarity of the voltage source in the sweep circuit to the initial state and finally release $\mathrm{RL}_{5}$ in order to made DC potential to be $0 \mathrm{~V}$. $\mathrm{RL}_{6}$ is also released by the release of $\mathrm{RL}_{5}$ late to $\mathrm{RL}_{10}$.

The same process as above repeats in synchronization with the mercury drop. 10) DC Polarographic Application.

DC polarogram such as Randles' single sweep polarogram can also be obtained by this equipment by applying the potential drop across the 'resistance to the $\mathrm{Y}_{D O}$-axis (1 $\mathrm{mV} . / \mathrm{cm}$ ) of the oscilloscope (refer to Fig. 2).

\section{Discussion and Conclusion}

The oscillographic square wave polarograph constructed in this laboratory has the following characteristics. The cathodic process and the anodic process can be observed 
continuosly, as the DC voltage sweeps triangularly between 0 and $-2 \mathrm{~V}$. Moreover this sweep is synchronized to the mercury drop, so the observation and also the theoretical interpretation of the oscillograms are easier than in the multi-sweep method.

The AC capacity current component can be effectively eliminated by the employment of the positive feedback technique and also by the gating technique. But the elimination of it at $0 \mathrm{~V}$. DC voltage is not satisfactory because of the extremely large capacity current. Moreover the DC capacity component, although very small, can not be eliminated. The employment of the stepwise DG voltage sweep may be effective in order to eliminate the DC capacity component. The sensibility and the stability of the present equipment as described in this paper were almost as well as the pen-recording AC (sine wave) polarograph. The improvement on these points is now undertaken in this Laboratory. Some interesting experimental results obtained with several organic and inorganic depolarizers will be also reported in the suceeding papers.

Finally the characteristics of the present oscillographic square wave polarograph are summarized as follows :

DC applied voltage: $\operatorname{span}=0 \sim-2 \mathrm{~V}$. (variable), sweeping rate $=4 \mathrm{~V} / \mathrm{sec}$ (variable), sweeping direction $=$ from 0 to $-2 \mathrm{~V}$. and reverse.

Superimposed square wave potential : frequency $=3 \mathrm{kc} / \mathrm{s}$, amplitude $=10 \mathrm{mV}_{p_{-}}$.

Gating : time $=$ after $145 \mu$ sec from each pulse of square wave potential, interval $=10$ $\mu$ sec.

\section{Acknowledgement}

The authors were very much indebted to Prof. Dr. Shuhei Kohmura (Waseda Univ.) for kind and valuable advices and to Director Munetoshi Matsui and Group Leader Dr. Akira Ito of our laboratory for affording facilities for this work.

\section{References}

1) G.C. Barker, Anal. Chim. Acta. 18, 118 (1958)

2) F.C. Snowden and H.T. Page, Anal. Chem. 22, 969 (1950)

3) H.M. David and J.E. Seacorn, Electronic Engineering, 25, 314 (1953)

4) A. Sevcik, Coll. Czech. Chem. Commun. 13, 349 (1948)

5) J.E.B. Randles, Trans. Farady Soc. 44, 327 (1948) 


$$
\begin{gathered}
\text { オッシログラフィック方形波ポーラログラフの試作 } \\
\text { (オッシログラフィック方形波ポーラログラフィー 第 } 1 \text { 報 })
\end{gathered}
$$

斉藤友紀雄, 岡本浩一

（三共株式会社研究所）

従来報告されているオッシログラブィックポーラロ グラフは，一般に直流分極毛圧下での直流ポーラログ ラムを観測するものであって，ベン式ポーラログラフ における交流ポーラログラフ法に刘応するものとして は詳しい報告はまだない様である。

したがつて著者等は電極反忍の研究および分析化学 的応用に新知識を得るために，新らたに交流オッシロ グラフィックポーラログラフ装置を試作した。

オッシログラフィックポーラログラフでは，直流電压 の掃引速度が比較的大きく，更にてれに重畳する交流 電圧の周期も高周波領域になるため, 電気二重風の充 放電による荷電電流成分が非常に顕著になる。したが つて交流オッシログラフィックポーラログラフを試作 するに際してはての衙電電流成分を除去する必要があ る。

著者等はこのために Barker の方形波法を用いて衔 電電流成分をゲート回路によつて除く事を試みた。し かしながら Barker の方形波法における様に重思方形 波の周期が充電電流の㭙定数に比して充分大きい㭙に は洋にゲートを行なうだけで有效であるが，オッシロ グラフ法の場合には数 $\mathrm{KC} / \mathrm{s}$ の方形波を使用するため この方法のみでは不充分であつて洐電電流成分を除く 舟はほとんどできなかつた。したがつて，著者箵は Fig. 1 亿示した様に，まず檪極を堌幅器によつて馲動 させその出力を增幅器の入侧に正㴆還して荷電電流 の祢定数を大きく減少させる事によつて充分な効果を 得る事ができた。(Fig. 4) ての方法によつて方形波 電压によつて生じる街電電流はほとんど完全に除去で きる。

一方直流加電纴は従来の Randles 型のものでは, 水銀滴の成長落下に周期させた single sweep 法と, 水銀滴に無関係な multi-sweep 法とがあるが，後者 は観測上および理論的取扱上不利な点が多いので著者
等は single sweep 法による事としたが，新らたに陽 極側掃引過程を設けて還元に引続いて再酸化が行なわ れる様にした。このためには論理问路がかなり複雑な ものとなるため, 㨁流電圧の掃引開始信号を零加電山: 附近における大きな街電電流成分を利用して得る方法 を考案し比較的簡単な論理回路ですむ様にした。 (Fig. 12, 13)

以上の様な考えに基づいて試作した装置のブロック ダイヤグラムは Fig. 2 に示した.

本ポーラログラフは荷電電流を含まない方形波ポー ラログラムをオッシロスコープによつて観測するもの であり，試作装置の特性は次の様になる。

1) 交流オッシログラフィックポーラログラムの観 測および二現象オッシロスコープを用いるため, 同時 に直流ポーラログラムの観測ができる。

2) 直流加電圧は原則として 0 から $-2 \mathrm{v}$. および - 2 から $0 \mathrm{v}$. へと連続的に掃引儿，乙のため 還元波 および 再酸化波が連続して 観測できる。加電圧速度 (4 v./sec.) および加電圧範䧃はいづれも可変である.

3) 電圧掃引は水銀滴の成脣に同期させてあり，常 に同一の成辰段階において水銀滴一滴につき一同だけ 行なわれる。

4) 重基方非波は周期 $3 \mathrm{KC} / \mathrm{s}$ ，振幅 $10 \mathrm{mv} \cdot p_{p}$ ○ ものを用いた。

5 ）ゲートは方形波電压の各立上りから $145 \mu \mathrm{sec}$

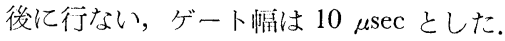

6) 侽電電流を除去するための正帚還问路への入力 は可変であつてポーラログラムを観測しながら調節す る事ができる。

以上の様に試作したオッシログラフィック方形波ポ 一ラログララフの電父的特性，回路について詳紼に報 告した. 